\title{
Influence of country of origin image on brand equity of consumers in Bosnia and Herzegovina: the case of smartphone market
}

\author{
Утицај земље порекла на имовинску вредност бренда \\ код потрошача у Босни и Херцеговини: пример тржишта \\ паметних телефона
}

\author{
Nikola Gluhović* \\ University of East Sarajevo, Faculty of Economics, Bosnia and Herzegovina, \\ nikola.gluhovic@yahoo.com
}

\begin{abstract}
Consumers pay attention to the country of origin when purchasing imported products and believe that it has a significant impact on the formation of consumer attitude towards branded products. Competition among global smartphone brands is an intense, efficient and effective branding strategy, an important prerequisite for accelerating market growth and gaining a competitive market position. The purpose of this paper is recognized in assessing the impact of country of origin image, perceived quality, brand associations and brand loyalty on the consumer-based brand equity (CBBE) formation process, as exemplified by two global smartphone brands, Samsung and Huawei in Bosnia and Herzegovina. For the purposes of the study, a survey was conducted using a questionnaire on a sample of 315 respondents. The survey results indicate that country of origin image and perceived quality play a more important role in buyers in Bosnia and Herzegovina for Chinese (Huawei) than South Korean (Samsung) smartphones. This suggests that buyers from Bosnia and Herzegovina are paying more attention to the quality of Chinese compared to South Korean smartphones.
\end{abstract}

Keywords: country of origin, consumer-based brand equity, perceived quality, brand associations, smartphone, Bosnia and Herzegovina

JEL classification: M15, M31

Сажетак: Потрошачи посвећују пажњу земљи порекла код куповине увозних производа те сматрају да она има значајан утицај на формирање потрошачког става према брендираним производима. Конкуренција међу глобалним брендовима паметних телефона је интензивна, па је ефикасна и ефективна стратегија брендирања важан предуслов за убрзани раст тржишта и стицање конкурентног тржишног положаја. Циљ овог рада препознат је у процени утицаја имиџа земље порекла, перципираног квалитета, асоцијација на бренд и лојалности бренду на процес формирања имовинске вредности бренда засноване на потрошачу, посматрано на примеру два глобална бренда паметних телефона, Самсунг и Хуавеј на подручју Босне и Херцеговине. За потребе рада спроведено је истраживање коришћењем анкетног упитника на узорку од 315 испитаника. Резултати истраживања указују да имиџ земље порекла и перципирани квалитет имају важнију улогу код купаца у Босни и Херцеговини за кинески (Хуавеј) у односу

Corresponding author 
на јужнокорејски (Самсунг) паметни телефон. То сугерише да купци из Босне и Херцеговне посвећују више пажње квалитету кинеских у односу на јужнокорејске паметне телесоне.

Кључне речи: земља порекла, имовинска вредност бренда заснована на потрошачу, перципирани квалитет, асоцијације на бренд, паметни телефон, Босна и Херцеговина.

JEL класификација: M15, M31

\section{Introduction}

In today's globalized market, consumers face an increasing supply of products, while businesses are under competitive pressure from domestic and global branded products. In such business conditions, it is necessary for companies to create adequate brand equity by forming a basis for enhancing competitive differentiation and gaining competitive advantage in the market. Consumer-Based Brand Equity (CBBE) is critical to managing a product, differentiating a brand, evaluating brand performance and maintaining a recognizable image in the market and in consumer awareness (Gluhović, 2014, p. 57). Consumers are strongly influenced by the brand when it comes to product selection. A strong and clear brand image instills greater confidence when shopping. In addition, the branding strategy should be a connective tissue that intertwines the brand image and reflects the brand value. An effective branding strategy should elicit and create distinctive linkages between the brand and the target consumers, seeking to maintain, enhance and shape, for the interests of the business, appropriate consumer behavior over the long term, ultimately resulting in greater consumer-based brand value (Keller, 2013). When a consumer decides to buy an imported product, they usually consider and evaluate two types of stimuli. Consequently, we can define stimuli as information stimuli that are available to consumers before purchase, distinguishing external and internal. Consumers evaluate internal stimuli (taste, design or components of a product) and / or external stimuli (brand, price, country of origin - COO) as they make their purchasing decisions. In the buying decision process, when consumers are more involved in a particular product category (smartphone purchase), they are likely to be more careful and selective when evaluating purchase stimuli, most of all during the decision making process they will rely on the selected and most importantly stimuli. On the other hand, the country of origin represents one of the most commonly selected external stimuli by consumers (Moradi \& Zarei, 2012, p. 402). The country of origin can be an important factor influencing the purchase of imported products or smartphones. In the event that consumers are faced with buying imported brands, the country of origin can crucially affect their pre-purchase behavior as well as their attitude towards a particular brand.

In developing countries, consumers are relatively high in preference to buying imported products, especially in cases of low price or a satisfactory relationship between quality and price of the product. When buying imported products, for which the country of origin is very important, consumers pay due attention to it because it has a significant impact on purchases (Moradi \& Zarei, 2012, p. 401-405). Saydan (2013) 
considers that consumer perception of the image of the country of origin influences the choice of branded product; on the other hand, the author emphasizes that the country of origin, perceived quality, brand associations and brand loyalty are the basic components of brand equity. Consequently, the "country effect" is a factor critical to realizing the market performance of a brand (or product) in a foreign market. Therefore, we consider the claim that the purchase of branded products is significantly influenced by the image of the country of origin (Kim \& Chao, 2018, p.70-73).

We chose the Bosnia and Herzegovina smartphone market to analyze the impact of country of origin image, in our case of imported products (smartphones), on the domestic consumers' purchasing decision, as exemplified by the Samsung and Huawei brands. Accordingly, in the second quarter of 2016, the market research agency GfK $\mathrm{BH}$ conducted a survey on the ownership and use of smartphones. Survey results showed that $39.5 \%$ of citizens of Bosnia and Herzegovina (BiH) over the age of 15 own a smartphone, an increase of $24 \%$ compared to data obtained at the end of 2012. The highest percentage of smartphone users is among the population aged 15-24, as many as $78.9 \%$ of the said population owns a smartphone. As expected, the smallest percentage of smartphone owners are among the oldest $(65+)$ in the population $-6.9 \%$ (GfK BH, 2018). The best-selling smartphone brands in Bosnia and Herzegovina are Samsung, Huawei and Apple, while competition among these brands is fierce. In order to maintain their position as major players in the mobile phone market in Bosnia and Herzegovina, it would be useful for these brands to have a clear understanding of what determines a consumer's choice of smartphone and what are the sources of consumerbased brand equity. Understanding the brand equity structure involves incorporating determinants such as perceived quality, brand associations, and brand loyalty into the formulation of a branding strategy, enabling more effective and deeper engagement with consumers. Branding strategy plays an integrative role in gaining and maintaining long-term competitive advantage (Moradi \& Zarei, 2012; Sudarević \& Marić, 2018). In addition, strong brands are leaders in the field of competitive advantage, increase cash flows of businesses, boost liquidity, ensure premium prices, profitability and increase consumer loyalty. The derived objective of this paper is to conduct a comparative analysis of the impact of country of origin image (South Korea vs. China) on the brand equity of two global smartphone brands (Samsung vs. Huawei) among consumers in Bosnia and Herzegovina.

\section{Literature review}

The country of origin image acts as a "halo effect" and is a concise overview of the branded product in the minds of consumers. The country of origin image acts as a "halo effect" even when the consumer is unfamiliar with the particular product, while acting as a concise overview when consumers have previously known the product and/or the brand. On the other hand, when consumers are unfamiliar with a brand or product, the country of origin serves as a strong external stimulus because many internal stimuli 
such as quality and performance are difficult to evaluate properly and objectively. Thus, consumers prefer products or brands made in countries with high image origin.

The country of origin effect is one of the most studied constructs in marketing and consumer behavior, beginning in 1965 when R. Schooler conceptualized the aforementioned construct (Roth \& Diamantopoulos, 2009, p. 731). Country of origin is defined as the country in which the product is manufactured. In some studies, the „Made in China" country of origin has become one of the most visible elements of differentiation, conveying both positive and negative meanings about China-made products and the image of China-related products as the country of production (Han \& Wang, 2012; Harney, 2008). Recent events involving the withdrawal of harmful children's toys, the dairy scandal and toxic drugs have compromised the image of Made in China, raising consumer concerns about the purchase of products made in China, which may increase image problems of Chinese products and/or brands, but also for China as a whole. The country of origin image serves as an external information stimulus to create consumer perceptions and product valuations, often acting as a signal of product quality, perceiving consumer risk and likelihood of purchasing (Phau \& Chao, 2008 , p. 350-352). At the same time, the country of origin image of imported products has a significant impact on consumer perceptions and is an important external construct that influences consumer behavior when choosing branded products (Gluhović, 2019).

In other words, the strength of the brand rests in the mind of the consumer and is identified with the image and quality of the product. Brand equity is recognized as a key indicator of market performance, a source of competitive advantage, and a vital component of business operations (Christodoulides et al., 2015). High brand equity is possible when generating a positive connotation about the brand in the minds of consumers, and it is therefore likely that consumers will prefer to buy that brand over other branded or non-branded products, while creating brand loyalty (Kuhn et al., 2008). The concept of consumer-based brand equity is considered to be the dominant framework, which is used in many marketing studies since it encourages the creation of appropriate brand positioning (Davcik \& Sharma, 2015, p.769; Matović et al., 2019). Consumerbased brand value is a set of consumer perceptions, attitudes, knowledge and behavior that results in increased customer service, higher returns or higher margins for businesses than would be possible without a brand (Christodolides \& Chernatory, 2010). Therefore, high-value brands can earn a premium price for their products (Kuhn et al., 2008; Kim \& Chao, 2018).

\section{Research methodology}

The paper assumes that the country of origin has an exogenous effect on the process of creating brand equity based on the consumer, directly affecting the perceived quality and forming brand associations with consumers, which again affect brand loyalty. The image of the country of origin strongly influences the creation of consumers' perceptions of products or brands, including quality assessment (Roth \& Romeo, 1992). 
Research hypotheses:

H1: The country of origin image of the Samsung (South Korea) and Huawei (China) brands has a positive effect on perceived quality with consumers in Bosnia and Herzegovina.

H2: The country of origin image of the Samsung (South Korea) and Huawei (China) brands positively influences the formation of brand associations with consumers in Bosnia and Herzegovina.

H3: Samsung and Huawei's perceived brand quality has a positive effect on brand loyalty with consumers in Bosnia and Herzegovina.

H4: Samsung and Huawei smartphone brand associations have a positive effect on brand loyalty with consumers in Bosnia and Herzegovina.

As we pointed out earlier, for the purposes of this paper, two countries of origin were selected, South Korea and China, and two brands Samsung and Huawei in the category of smartphones for assessing consumer perception and behavior in Bosnia and Herzegovina. The two brands and relevant countries of origin were selected for the following reasons: (a) smartphones belong to the category of high-involvement shopping products, where consumers spend a lot of time collecting and searching for information, while on the other hand, brand and country of origin represent two important elements in the information search process, (b) Samsung and Huawei are two brands that occupy a significant share of the smartphone market in Bosnia and Herzegovina, indicating a high level of recognition of these products with consumers .

The approach used for measurement was chosen based on previous studies: country-of-origin construct (Moradi \& Zarei, 2012; Shirin \& Kambiz, 2011), perceived quality (Jalilvand et al., 2011), brand associations, and brand loyalty (Moradi \& Zarei, 2012). Measuring consumer attitudes was done using a five-point Likert scale $(1=$ disagree at all, $2=$ disagree, $3=$ indifferent, $4=$ agree, and $5=$ strongly agree). The questionnaire method was used to collect the data. In order to collect the data from the questionnaire, the respondents in Bosnia and Herzegovina were contacted through the social network Facebook, and the questionnaire link was distributed through the online method. All respondents participated in the survey voluntarily. The questionnaire contained sixteen questions pertaining to Samsung and Huawei smartphone research and six general questions (demographics). A total of 335 questionnaires were collected and 315 completed questionnaires were processed. Statistical processing and analysis of the data were performed using the SPSS software package (19.0). Using exploratory and confirmatory factor analysis, the corresponding indices were measured to measure the validity of the proposed model. Following these analyses, the impact of the country of origin image variable on perceived quality and brand associations was analyzed, followed by the analysis of the impact of perceived quality and brand loyalty associations 
on the purchase of Samsung and Huawei smartphones by consumers in Bosnia and Herzegovina. The hypotheses were tested in this way.

\section{Research results}

A preliminary analysis of the data collected showed the participation of approximately $50 \%$ of male and $50 \%$ of female respondents. The survey mostly refers to respondents aged 21-30 years with a university degree. In terms of smartphone use, $18 \%$ of those surveyed stated that they were using Iphone, while $41 \%$ and $32 \%$ of the market was occupied by Samsung and Huawei respectively, the rest of the market belonged to other brands.

For research purposes we used Exploratory Factor Analysis - EAF for Samsung and Huawei brands. The results show that four factors were investigated (country of origin, perceived quality, brand associations and brand loyalty), and certain dimensions of individual factors for the observed brands were entered. The EAF results show that the dimensions studied had a satisfied requirement, i.e. a value above 0.5. Cronbach's Alpha $(\alpha)$ resulted in 16 items that were statistically acceptable, for both Samsung and Huawei, Composite Reliability (CR) was higher than 0.7, while Average Variance Extracted (AVE) exceeded 0.5 at the same time confirming the existence of convergent validity.

The compliance indicators for the research model are shown in Table 1. Given that the value of the indicator $\chi 2 / d f$ should be less than 3 (Bagozzi \& Yi, 1988), it can be observed that this condition is fulfilled. Accordingly, the results of the Confirmatory Factor Analysis (CFA) and statistically $\chi^{2}$ df for Samsung indicate the correctness of the fitted model $(\mathrm{CMIN} / \mathrm{DF}=1.402$; NFI $=0.98$; $\mathrm{CFI}=1.00$; $\mathrm{TLI}=0.99$; $\mathrm{RMSEA}=$ $0.021)$. The results of applying $\chi^{2} \mathrm{df}$ for Huawei also show a satisfactory fit to the measurements performed $(\mathrm{CMIN} / \mathrm{DF}=1.178$; $\mathrm{NFI}=0.98$; $\mathrm{CFI}=0.99$; $\mathrm{TLI}=0.98$; RMSEA $=0.045)$. The result can be justified by the fact that a large sample and a complex research model lead to a low $p$ value and, consequently, to the statistical significance of the Hi-square test (Hair et al., 2010). The NFI, CFI and TLI index values should be above 0.9 (Byrne, 1998), so it can be concluded that the model fulfills these compliance conditions. Finally, the value of the RMSEA should be lower than 0.08 (Hair et al., 2006), which is met in the model. 
Table 1: Indicators of conducted measurements for Confirmatory Factor Analysis (CFA)

\begin{tabular}{|l|c|c|c|}
\hline \multicolumn{1}{|c|}{ Indicators } & Samsung & Huawei & Recommended value \\
\hline$\chi^{2} \mathrm{df}$ & 1.402 & 1.178 & $\leq 3.00$ \\
\hline Comparative fit index (CFI) & 1.00 & 0.99 & $\geq 0.90$ \\
\hline Normal Fit Index (NFI) & 0.98 & 0.98 & $\geq 0.90$ \\
\hline Tucker-Lewis Index (TLI) & 0.99 & 0.98 & $\geq 0.90$ \\
\hline $\begin{array}{l}\text { The Root Mean Square Error of Approximation } \\
\text { (RMSEA) }\end{array}$ & 0.021 & 0.043 & $\leq 0.08$ \\
\hline
\end{tabular}

Source: Author Survey (SPSS Statistics 19)

The survey results show a statistically significant and positive relationship between country of origin, perceived quality, brand associations and brand loyalty.

Table 2: Indicators of confirmatory factor analysis

\begin{tabular}{|c|c|c|c|c|}
\hline $\begin{array}{l}\text { Variables and Dimensions for Samsung and } \\
\text { Huawei, respectively (AVE, CR) }\end{array}$ & $\begin{array}{l}\text { Factor } \\
\text { loading } \\
\text { Samsung }\end{array}$ & $\begin{array}{l}\text { Factor } \\
\text { loading } \\
\text { Huawei }\end{array}$ & $\begin{array}{c}\alpha \\
\text { Samsung }\end{array}$ & $\begin{array}{c}\alpha \\
\text { Huawei }\end{array}$ \\
\hline Country of origin $(0.651 ; 0.906) ;(0.631 ; 0.895)$ & & & 0.908 & 0.901 \\
\hline $\begin{array}{l}\text { Is your stance on Samsung or Huawei shaped by } \\
\text { their country of origin, South Korea or China, } \\
\text { respectively? }\end{array}$ & 0.845 & 0.767 & & \\
\hline $\begin{array}{l}\text { The Samsung or Huawei country of origin is a } \\
\text { country with a high level of technological } \\
\text { advantage. }\end{array}$ & 0.812 & 0.796 & & \\
\hline $\begin{array}{l}\text { The Samsung or Huawei country of origin is a } \\
\text { design good country. }\end{array}$ & 0.786 & 0.689 & & \\
\hline $\begin{array}{l}\text { Samsung or Huawei is the country of origin of high } \\
\text { quality products. }\end{array}$ & 0.889 & 0.789 & & \\
\hline Perceived quality $(0,756 ; 0,918) ;(0,608 ; 0,889)$ & & & 0.917 & 0.897 \\
\hline Samsung or Huawei is a trusted brand. & 0.881 & 0.757 & & \\
\hline $\begin{array}{l}\text { Samsung or Huawei is a brand that can be bought } \\
\text { at an affordable price. }\end{array}$ & 0.837 & 0.831 & & \\
\hline $\begin{array}{l}\text { Samsung or Huawei is a brand whose price is in } \\
\text { line with quality. }\end{array}$ & 0.889 & 0.896 & & \\
\hline $\begin{array}{l}\text { I'm ready to pay a higher price for the Samsung } \\
\text { brand or Huawei. }\end{array}$ & 0.834 & 0.826 & & \\
\hline Brand associations $(0,617 ; 0,889) ;(0,597 ; 0,873)$ & & & 0.892 & 0.878 \\
\hline
\end{tabular}




\begin{tabular}{|c|c|c|c|c|}
\hline $\begin{array}{l}\text { Samsung or Huawei brand country of origin } \\
\text { associations are countries with prestigious } \\
\text { manufacturing status. }\end{array}$ & 0.826 & 0.817 & & \\
\hline $\begin{array}{l}\text { Samsung or Huawei brand country of origin } \\
\text { associations is a country that is innovative in } \\
\text { manufacturing. }\end{array}$ & 0.819 & 0.791 & & \\
\hline $\begin{array}{l}\text { Samsung or Huawei is a brand that has a good } \\
\text { reputation. }\end{array}$ & 0.776 & 0.801 & & \\
\hline Samsung or Huawei is an attractive brand. & 0.679 & 0.654 & & \\
\hline Brand loyalty $(0.801 ; 0.957) ;(0.771 ; 0.927)$ & & & 0.951 & 0.913 \\
\hline $\begin{array}{l}\text { Samsung or Huawei is a brand that meets customer } \\
\text { expectations. }\end{array}$ & 0.925 & 0.889 & & \\
\hline $\begin{array}{l}\text { Samsung or Huawei brand is my first choice when } \\
\text { buying smartphones. }\end{array}$ & 0.878 & 0.861 & & \\
\hline $\begin{array}{l}\text { I'm ready to recommend a friend buy a Samsung or } \\
\text { Huawei smartphone. }\end{array}$ & 0.852 & 0.863 & & \\
\hline $\begin{array}{l}\text { Will you buy a Samsung or Huawei smartphone } \\
\text { after your first purchase? }\end{array}$ & 0.914 & 0.895 & & \\
\hline
\end{tabular}

Source: the author's calculation

Internal consistency and convergent validity were satisfied for all four reflective constructs, AVEs and composite reliability values are greater than 0.5 and 0.7 , respectively (Becker et al., 2012). Consequently, the condition of divergent validity was satisfied by establishing the Fornell - Larcker criterion (Table 3). In addition, analysis of the Cronbach's alpha coefficient revealed that all variables had a corresponding level of internal consistency higher than 0.7 (Nunnally, 1978). In addition to the above results, it should be noted that the highest number of findings has very high values of factor loadings (greater than 0.7 ).

Table 3: Divergent validity - Fornell - Larcker criterion

\begin{tabular}{|l|c|c|c|c|}
\hline & Country of origin & Perceived quality & Brand associations & Brand loyalty \\
\hline Country of origin & 0.796 & & & \\
\hline Perceived quality & 0.751 & 0.826 & & \\
\hline Brand associations & 0.653 & 0.773 & 0.801 & \\
\hline Brand loyalty & 0.702 & 0.649 & 0.514 & 0.786 \\
\hline
\end{tabular}

Source: Author calculation 
After testing the model, it can be concluded that the claim regarding the price/quality ratio of the brand is a significant indicator of perceived quality. The relationships between all reflective constructs are further analyzed in the paper.

Estimated path coefficients between country of origin and perceived quality are statistically significant, for Samsung amounts (path coefficient $=0.305$ with positive $p$ value for $\mathrm{p}<0.001$ ) and for Huawei brand (path coefficient $=0.324, \mathrm{p}<0.001$ ) (Figure 1). It is necessary to make statistical adjustments to the two model structures for the Samsung and Huawei brands; the results suggest that the structural models are (CMIN / $\mathrm{DF}=1.5 ; \mathrm{NFI}=0.97$; CFI $=0.98 ; \mathrm{TLI}=0.99 ; \mathrm{RMSEA}=0.04$ ) for Samsung brand $(\mathrm{CMIN} / \mathrm{DF}=1.5 ; \mathrm{NFI}=0.97 ; \mathrm{CFI}=0.99 ; \mathrm{TLI}=0.98 ; \mathrm{RMSEA}=0.041)$ and for Huawei

Figure 1 Path coefficients of the research model

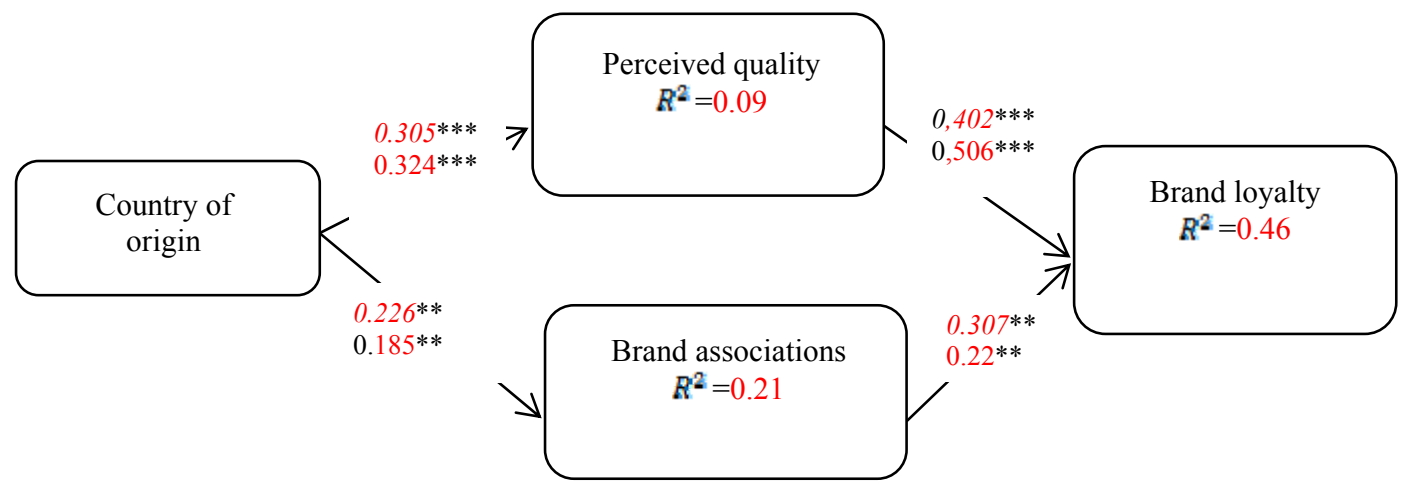

Note: ** significant $p<0.01 ; * *$ significant $p<0.001$. Path coefficients for Samsung in italic numbers.

The image of the country of origin also positively influences brand associations for both Samsung and Huawei smartphones (path coefficient $=0.226 ; 0.185$, respectively; statistical significance for $\mathrm{p}<0.01 ; \mathrm{p}<0.01$ ). Constructs perceived quality and brand associations directly influence the brand loyalty construct (path coefficient $=$ 0.402; $\mathrm{p}<0.001$; path coefficient $=0.307 ; \mathrm{p}<0.01$ ) for Samsung and Huawei (path coefficient $=0.506 ; \mathrm{p}<0.001 ;$ and path coefficients $=0.22 ; \mathrm{p}<0.01$, respectively Samsung and Huawei smartphones represent the two leading brands with dominant positions in the market of Bosnia and Herzegovina, and customers have different perceptions of these brands.

\section{Discussion}

Earlier, we pointed out that the aim of this paper is to recognize the impact of the country of origin on perceived quality and brand associations, and on brand loyalty as a core component of consumer-based brand equity in the case of the smartphone market in 
Bosnia and Herzegovina, looking at two dominant foreign countries brands from South Korea (Samsung) and China (Huawei). Given the growing popularity and reputation of these two smartphone brands in Bosnia and Herzegovina (B\&H), the overall work contributes to the existing literature in shedding light on the issue. The online survey was conducted in Bosnia and Herzegovina on a sample of 315 respondents, with the results of the survey confirming that the image of South Korea and China's country of origin (COO) influences the formation of perceived quality (PQ) and brand associations (BA) among smartphone buyers (Samsung and Huawei) in Bosnia and Herzegovina. Overall, the country of origin construct has a greater impact on perceived quality (PQ) compared to brand associations (BA) for Samsung and Huawei brands (Table 4).

Table 4: Path analysis results for Samsung and Huawei

\begin{tabular}{|l|c|c|c|c|}
\hline & \multicolumn{2}{|c|}{ Path Coefficient Estimates } & \multicolumn{2}{|c|}{$P$} \\
\hline $\begin{array}{l}\text { Path } \\
\text { Relationship }\end{array}$ & $\begin{array}{l}\text { Samsung } \\
\text { (S.Korea) }\end{array}$ & Huawei (China) & $\begin{array}{c}\text { Samsung } \\
\text { (S.Korea) }\end{array}$ & Huawei (China) \\
\hline $\mathrm{COO} \rightarrow \mathrm{PQ}$ & $.305^{* * *}$ & $.324^{* * *}$ & $<0.001$ & 0.01 \\
\hline $\mathrm{COO} \rightarrow \mathrm{BA}$ & $.226^{* *}$ & $.185^{* *}$ & 0.012 & 0.033 \\
\hline $\mathrm{PQ} \rightarrow \mathrm{BL}$ & $.402^{* * *}$ & $.506^{* * *}$ & $<0.001$ & $<0.001$ \\
\hline $\mathrm{BA} \rightarrow \mathrm{BL}$ & $.307^{* *}$ & $.22^{* *}$ & 0.003 & 0.002 \\
\hline
\end{tabular}

Note: ** significant for $p<0.01$; *** significant for $p<0.001$. Source: Author Survey (SPSS Statistics 19)

In other words, perceived quality (PQ) of foreign brands is a key driver in determining the choice of smartphone buyers in Bosnia and Herzegovina. The brand association (BA) construct also influences the decision to buy these smartphones, but the performance is lower compared to perceived quality (PQ). This implies that perceived quality (PQ) is more influenced by branding intention with customers in Bosnia and Herzegovina for Samsung and Huawei smartphone brands than brand associations (BA).

Table 4 lists the different path coefficients between the two (perceived quality and brand associations) selected constructs (Samsung and Huawei) of the ConsumerBased Brand Equity (CBBE) model. Huawei's perceived quality (PQ) is more influenced by the country of origin (COO) image than is the case with Samsung, implying that the Chinese country of origin (COO) image has a significantly greater impact on the perceived quality (PQ) of the Chinese smartphone in Bosnia and Herzegovina. On the other hand, the South Korean image of the country of origin (COO) is more strongly influenced by the formation of positive brand associations (BA) with Samsung compared to the Huawei brand. The South Korean country of origin (COO) image is closely linked to the formation of brand associations (BA) by Samsung, leading to increased brand loyalty (BL) among customers in Bosnia and Herzegovina. Consequently, Samsung has a relatively larger market share than Huawei and implements more promotional and branding activities in Bosnia and Herzegovina, which creates a potentially 
greater number of sources of information from which customers generate stimuli when associating Samsung brand with their country of origin (South Korea). The country of origin image (South Korea) is strongly associated with positive associations with the Samsung brand. The Samsung brand actively uses and exerts positive value in its advertising and branding campaigns, which is a positive aspect of the South Korean image of the country of origin. Therefore, Samsung's advertising and branding campaign effectively increases brand affiliation, resulting in greater customer loyalty to its products. In general, Samsung brand associations (BA) are relatively more pronounced than those of the Huawei brand, while the country of origin image has a more positive effect on Samsung's CBBE brand equity.

Table 5: Verification the relationship between variables in the structural model

\begin{tabular}{|l|c|c|c|c|}
\hline \multirow{2}{*}{ Hypothesis } & \multicolumn{2}{|c|}{ Assessment } & \multicolumn{2}{c|}{ Conclusion } \\
\cline { 2 - 5 } & $\begin{array}{l}\text { Samsung } \\
\text { (S.Korea) }\end{array}$ & $\begin{array}{c}\text { Huawei } \\
\text { (China) }\end{array}$ & $\begin{array}{c}\text { Samsung } \\
\text { (S.Korea) }\end{array}$ & $\begin{array}{c}\text { Huawei } \\
\text { (China) }\end{array}$ \\
\hline $\begin{array}{l}\text { H1: Country of origin image } \rightarrow \\
\text { perceived quality }\end{array}$ & $.305^{* * *}$ & $.324^{* * *}$ & accepted & accepted \\
\hline $\begin{array}{l}\text { H2: Image of country of origin } \rightarrow \text { brand } \\
\text { associations }\end{array}$ & $.226^{* *}$ & $.185^{* *}$ & accepted & accepted \\
\hline H3: Perceived quality $\rightarrow$ brand loyalty & $.402 * * *$ & $.506^{* * *}$ & accepted & accepted \\
\hline H4: Brand associations $\rightarrow$ brand loyalty & $.307^{* *}$ & $.22^{* *}$ & accepted & accepted \\
\hline
\end{tabular}

Note: ** significant for $p<0.01$; *** significant for $p<0.001$. Source: Author Survey (SPSS Statistics 19)

The country of origin image (COO) is influential in shaping the consumer attitude towards foreign brands. This particularly affects consumers' perceptions of product quality, which ultimately affects their choice of a particular brand. Regarding the impact of the country of origin image (COO) on the property value of the brand based on the consumer, the research findings obtained in this paper are supported by previous research (Murtiasih \& Siringoringo, 2013; Mostafa, 2015). Various studies confirm the relationship between the country of origin image $(\mathrm{COO})$ and the value of the brand based on the consumer. Pappu et al. (2007, p. 730) have demonstrated and demonstrated that the image of the US country of origin has a positive effect on consumer-based brand equity for IBM and Apple brands in the Australian market. The aforementioned study clearly shows that the country of origin image influences key dimensions of brand equity such as perceived quality, brand associations and brand loyalty.

\section{Conclusion}

The research findings support a positive relationship between the construct country of origin image and the main components of a consumer-based brand value, perceived quality, brand associations, and brand loyalty. Previous research has offered similar results for the brand property structure, viewing consumer-based brand value as a multidimensional concept with causal relationships among its components. Han \& Wang 
(2012) proved that perceived quality has a greater impact on brand loyalty compared to brand associations. These research findings suggest the importance of ensuring high quality in consumer awareness as a necessary activity to establish consumer loyalty. Our research results have unequivocally shown that perceived quality has the biggest impact on Samsung and Huawei brand loyalty. For Samsung, country of origin and brand associations are equally important for brand loyalty, on the other hand, country of origin has a much greater effect on the Huawei brand than brand associations. This suggests that consumers in Bosnia and Herzegovina pay far more attention to the quality of "Chinese" smartphones than to "South Korean" products. Furthermore, the perceived quality of Chinese products has a stronger effect on consumer preferences compared to South Korean products.

South Korea has improved the country of origin image in recent decades, primarily by increasing the number of foreign tourists who have visited it. In 2010, the number of foreign visitors to South Korea amounted to 8.8 million people (an increase of $12.5 \%$ compared to 2009) (Yu et al., 2012). Some authors attribute the influence of South Korean popularity to South Korean drama and pop music, which are reportedly contributing to the rise in popularity of South Korean products. In the case of China, „Made in China” products dominate the world market. Despite China's rapid economic growth as a leading manufacturer in the world, the quality of "Made in China" products is still considered negative. The "Made in China" effect has been known to have a negative impact on consumers over the last ten years (Ahmed et al., 2014). As the second largest economy, after the US, China has embarked on the development and production of many products to compete with foreign products. With its competitive rise, China seeks to enhance the country of origin's image in order to improve its position in the international market (Kim \& Chao, 2018).

China's rapid economic growth is expected to drive investment in the country of origin image while improving the products image made in China, while some authors believe that China will soon be more competitive in its country of origin mage (Yunus $\&$ Rashid, 2016). In short, the success of Chinese brands will largely depend on promoting product quality to make consumers more loyal. Finally, both South Korean and Chinese smartphone brands need to recognize and understand the significant role that the country of origin plays in creating consumer preferences, specifically in Bosnia and Herzegovina and beyond, and should develop effective market communication strategies, emphasizing and promoting product quality in order to gaining competitive advantage in the market.

\section{References}

Ahmed, Z. U., Johnson, J. P., Xia, Y., \& Chen, K. F. (2014). Does Country of Origin Matter for Low-Involvement Products? International Marketing Review, 21(1), 102120. Doi: https://doi.org/10.1108/02651330410522925 
Becker, J-M., Klein, K., \& Wetzels, M. (2012). Hierarchical Latent Variable Models in PLS-SEM: Guidelines for Using Reflective-Formative Type Models. Long Range Planning, 45 (5-6): 359-394. Doi: https://doi.org/10.1016/j.lrp.2012.10.001

Byrne, B. M. (1998). Structural Equation Modeling with LISREL, PRELIS, and SIMPLIS: Basic Concepts, Applications, and Programming, Hillsdale, New York: Lawrence Erlbaum.

Christodoulides, G., Cadogan, J., \& Veloutsou, V. (2015). Consumer-based brand equity measurement: Lessons from an international study. International Marketing Review, 32(3/4), 307-328. Doi: https://doi.org/10.1108/IMR-10-2013-0242

Christodoulides, G., \& Chernatony, L. (2010). Consumer-Based Brand Equity, Measurment: A Literature Review. International Market Research, 52(1), 43-65. Doi: https://doi.org/10.2501/S1470785310201053

Davcik, N., \& Sharma, P. (2015). Impact of product differentiation, marketing investments and brand equity on pricing strategies. European Journal of Marketing, 49(5/6), 760-781. Doi: https://doi.org/10.1108/EJM-03-2014-0150

GfK BH (2018). Istraživanje posjedovanja i korišćenja pametnih telefona u Bosni i Hercegovini, 2017. Sarajevo

Gluhović, N. (2014). Brend menadžment. Istočno Sarajevo: Zavod za udžbenike i nastavna sredstva.

Gluhović, N. (2019). Upravljanje luksuznim brendom. Istočno Sarajevo: Zavod za udžbenike i nastavna sredstva.

Hair, J. F., Black, W. C., Babin, B., Anderson, R., \& Tatham, R. (2006). Multivariate Data Analysis, 6th ed., New York: Prentice Hall.

Hair, J. F., Black, W. C., Babin, B., \& Anderson, R. (2010). Multivariate Data Analysis, 7th ed. Upper Saddle River, NJ: Prentice Hall.

Han, G., \& Wang, X. (2012). Understanding "Made in China": Valence framing and product-country image. Journalism \& Mass Communication Quarterly, 89(2), 225243. Doi: https://doi.org/10.1177/1077699012439034

Harney, A. (2008). The China price: The true cost of Chinese competitive advantage. New York: The Penguin Press.

Jalilvand, M. R., Samiei, N., \& Mahdavinia, S. H. (2011). The effect of brand equity components on purchase intention: An application of Aaker's model in the automobile industry. International business and management, 2(2), 149-158. Doi:

http://dx.doi.org/10.3968/j.ibm.1923842820110202.016 
Keller, K. L. (2013). Strategic Brand Management: Building, Measuring, and Managing Brand Equity. Boston, MA: Pearson.

Shirin, K., \& Kambiz, H.H. (2011). The Effect of the Country-of-Origin Image, Product Knowledge and Product Involvement on Consumer Purchase Decisions, Chinese Business Review, 10(8), 601-615.

Kim, R.B., \& Chao, Y. (2018). The effect of country of origin on consumer brand equity (CBBE) of Colombian consumers. Journal of International Studies, 11(3), 70-81.

Kuhn, K. A. L., Alpert, F., \& Pope, N. K. L. (2008). An application of Keller's brand equity model in a B2B context. Qualitative Market Research: An International Journal, 11(1), 40-58. Doi: https://doi.org/10.1108/13522750810845540

Matović, V., Stanić, M., \& Drinić, I. (2019). Impact branding on consumer preference towards buying a certain product: Comparative analysis of brands Nike and Adidas. Ekonomika, 65(3), 35-44. Doi: https://doi.org/10.5937/ekonomika1903035M

Moradi H., \& Zarei A. (2011). The Impact of Brand Equity on Purchase Intention and Brand Preference-the Moderating Effects of Country of Origin Image, Australian Journal of Basic and Applied Sciences, 5(3), 539-545.

Moradi, H., \& Zarei, A. (2012). Creating consumer-based brand equity for young Iranian consumers via country of origin sub-components effects. Asia Pacific Journal of Marketing and Logistics, 24(3), 394-413. Doi: https://doi.org/10.1108/13555851211237885

Mostafa, R. H. (2015). The Impact of Country of Origin and Country of Manufacture of a Brand on Overall Brand Equity. International Journal of Marketing Studies, 7(2), 70-83. Doi: https://doi.org/10.5539/ijms.v7n2p70

Murtiasih, S., \& Siringoringo, H. (2013). How word of mouth influence brand equity for automotive products in Indonesia. Procedia-Social and Behavioral Sciences, 81, 4044. Doi: https://doi.org/10.1016/j.sbspro.2013.06.384

Nunnally, J. C. (1978). Introduction to Psychological Measurement, New York: McGraw-Hill.

Pappu, R., Quester, P. G., \& Cooksey, R. W. (2007). Country image and consumerbased brand equity: relationships and implications for international marketing. Journal of International Business Studies, 38(5), 726-745. Doi:

https://doi.org/10.1057/palgrave.jibs.8400293

Phau, I., \& Chao, P. (2008). Country-of-origin: state of the art review for international marketing strategy and practice. International Marketing Review, 25(4), 349-353. Doi: https://doi.org/10.1108/imr.2008.03625daa.001 
Roth, K. P., \& Diamantopoulos, A. (2009). Advancing the country image construct. Journal of Business Research, 62(7), 726-740. Doi:

https://doi.org/10.1016/j.jbusres.2008.05.014

Roth, M. S., \& Romeo, J. B. (1992), Matching Product Category and Country Image Perceptions: A Framework for Managing Country-of-Origin Effects, Journal of International Business Studies, 23 (3), 477-497. Doi:

https://doi.org/10.1057/palgrave.jibs.8490276

Saydan, R. (2013). The relationship between Country of Origin Image and Brand Equity: Empirical Evidence in the English Market. International Journal of Business and Social Science, 4(3), 78-88.

Sudarević, T., \& Marić, D. (2018). Global brands in the digital era. Anali Ekonomskog fakulteta u Subotici, 39, 89-98. Doi: https://doi.org/10.5937/AnEkSub1839089S

Yu, H., Kim, C., \& Kim, H. (2012). Investigating cosmetics purchase of international tourists in South Korea. International Journal of Management Cases, 14(1), 398-410.

Yunus, N.M., \& Rashid E. W. (2016). The Influence of Country-of-origin on Consumer Purchase Intention: The Mobile Phones Brand from China. Procedia Economics and Finance, 37, 343-349. Doi: https://doi.org/10.1016/S2212-5671(16)30135-6 